\title{
in vivo antibacterial and therapeutic properties of $P$. ostreatus against Staphylococcus aureus
}

\author{
*Oyekanmi, B. A. ${ }^{1}$, Onifade, A. K. ${ }^{2}$, Osho, I. B. ${ }^{3}$, Ajayi O. T. ${ }^{4}$
}

\begin{abstract}
Objectives: The use of natural products is embraced by a larger percentage of the world population. Most species of fungi including mushrooms produce useful secondary metabolites that stimulate the immune system against infection and diseases. Investigations were conducted to assay the therapeutic potentials of $P$. ostreatus against pathogenic staph infection.
\end{abstract}

Methods: The methanol extract of $P$. ostreatus was prepared using the cold extraction method. Thirty Wistar albino rats weighing $82.0 \mathrm{~g}$ to $99.2 \mathrm{~g}$ were distributed into 6 groups of 5 and inoculated orally with actively growing Staphylococcus aureus suspension. P. ostreatus methanol extract LD ${ }_{50}>5000 \mathrm{mg} / \mathrm{kg}$ was used to determine the graded doses for the study. Graded doses of the extract $625 \mathrm{mg}, 1250 \mathrm{mg}$, and $2500 \mathrm{mg}$ were administered orally to the experimental animals for seven days.

Results: The negative control and $625 \mathrm{mg}$ had skin ulceration while $1250 \mathrm{mg}$ to $2500 \mathrm{mg}$ produced apparently healthy skin. Bacterial count after 7 days post-treatment was significantly high in the negative control and $625 \mathrm{mg}$ dose $\left(32.00 \times 10^{4} \pm 6.10^{\mathrm{b}} ; 43.40 \times 10^{4} \pm 6.20^{\mathrm{b}} \mathrm{Cfu} / \mathrm{ml}\right) \mathrm{P}<0.05$. Haematological and serum biochemical values were not significantly $\mathrm{P}<0.05$ affected. Pleurotus ostreatus administration at 1250 to $2500 \mathrm{mg}$ produced a statistically low colony count that was comparable with $13.33 \mathrm{mg}$ Ciprofloxacin and placebo.

Conclusion: Pleurotus ostreatus at 1250 to $2500 \mathrm{mg}$ was able to produce clinical recovery from S. aureus infection while $625 \mathrm{mg}$ could not. The extract had no deleterious effect on the blood parameters, liver enzymes, and kidney biomarkers.

Keywords: Pleurotus ostreatus, anti-staphylococcal, haematological, biochemical

\footnotetext{
*Corresponding author

Oyekanmi, B.A.

ORCID-NO: http://orcid.org/0000-000

Email:bolapeoyekanmi@yahoo.com

${ }^{1}$ Department of Haematology, College of Health Sciences, Osun State University, Osogbo, Nigeria.

${ }^{2}$ Department of Microbiology, Federal University of Technology, Akure, Nigeria.

${ }^{3}$ Department of Animal Production and Health, Federal University of Technology, Akure, Nigeria.

${ }^{4}$ Department of Microbiology, Federal University of Technology, Akure, Nigeria.
}

Research Journal of Health Sciences subscribed to terms and conditions of Open Access publication. Articles are distributed under the terms of Creative Commons Licence (CC BY-NC-ND 4.0). (http://creativecommons.org/licences/by-nc-nd/4.0).

http://dx.doi.org/10.4314/rejhs.v9i3.8 


\title{
propriétés antibactériennes et thérapeutiques in vivo de $P$. ostreatus contre Staphylococcus aureus
}

\author{
*Oyekanmi, B. A. ${ }^{1}$, Onifade, A. K. ${ }^{2}$, Osho, I. B. ${ }^{3}$, Ajayi O. T. ${ }^{4}$
}

\begin{abstract}
Resume
Objectifs: L'utilisation de produits naturels est adoptée par un plus grand pourcentage de la population mondiale. La plupart des espèces de champignons, y compris les champignons, produisent des métabolites secondaires utiles qui stimulent le système immunitaire contre les infections et les maladies. Des recherches ont été menées pour évaluer les potentiels thérapeutiques de $P$. ostreatus contre l'infection staphylococcique pathogène.
\end{abstract}

Méthodes: L'extrait au méthanol de P. ostreatus a été préparé en utilisant la méthode d'extraction à froid. Trente rats albinos Wistar pesant de 82,0 g à 99,2 g ont été répartis en 6 groupes de 5 et inoculés par voie orale avec une suspension de Staphylococcus aureus en croissance active. Un extrait méthanolique de P. ostreatus DL $50>5000$ $\mathrm{mg} / \mathrm{kg}$ a été utilisé pour déterminer les doses graduées pour l'étude. Des doses graduées de l'extrait de $625 \mathrm{mg}, 1250$ mg et $2500 \mathrm{mg}$ ont été administrées par voie orale aux animaux de laboratoire pendant sept jours.

Résultats: Le témoin négatif et $625 \mathrm{mg}$ présentaient une ulcération cutanée tandis que $1250 \mathrm{mg}$ à $2500 \mathrm{mg}$ produisaient une peau apparemment saine. La numération bactérienne après 7 jours post-traitement était significativement élevée dans le contrôle négatif et la dose de $625 \mathrm{mg}(32,00 \times 104 \pm 6,10 \mathrm{~b} ; 43,40 \times 104 \pm 6,20 \mathrm{~b}$ $\mathrm{Cfu} / \mathrm{ml}) \mathrm{P}<0,05$. Les valeurs hématologiques et biochimiques sériques n'étaient pas significativement affectées par $\mathrm{P}<0,05$. L'administration de Pleurotus ostreatus à raison de 1250 à $2500 \mathrm{mg}$ a produit un nombre de colonies statistiquement faible qui était comparable à $13,33 \mathrm{mg}$ de ciprofloxacine et à un placebo.

Conclusion: Pleurotus ostreatus à 1250 à $2500 \mathrm{mg}$ était capable de produire une guérison clinique de l'infection à $\mathrm{S}$. aureus alors que $625 \mathrm{mg}$ ne le pouvaient pas. L'extrait n'a eu aucun effet délétère sur les paramètres sanguins, les enzymes hépatiques et les biomarqueurs rénaux.

Mots clés: Pleurotus ostreatus, antistaphylococcique, hématologique, biochimique

*Corresponding author

Oyekanmi, B.A.

ORCID-NO: http://orcid.org/0000-000

Email:bolapeoyekanmi@yahoo.com

\footnotetext{
${ }^{1}$ Department of Haematology, College of Health Sciences, Osun State University, Osogbo, Nigeria.

${ }^{2}$ Department of Microbiology, Federal University of Technology, Akure, Nigeria.

${ }^{3}$ Department of Animal Production and Health, Federal University of Technology, Akure, Nigeria

${ }^{4}$ Department of Microbiology, Federal University of Technology, Akure, Nigeria.
} 


\section{INTRODUCTION}

Antimicrobial resistance and epidemics of infections from unknown origin necessitate a continuous search for drugs and antimicrobials from natural sources. It is therefore important to fortify and strengthen the immune system to face future health challenges of outbreaks of infectious and life-threatening diseases. Staphylococcus aureus causes boils, cross infections of wounds, ulcers, burns, and septicemia. Extracellular enzymes produced by $S$. aureus contribute to its invasiveness and pathogenicity (1). There are resistant strains of Staphylococcus aureus such as methicillinresistant $S$. aureus. These strains are resistant to Methicillin, related penicillin, and other common antibiotics. They are causative agents of hospital infections, especially wound infections and septicemia (1).

Mushrooms have been found useful as a food source and traditional medicines around the world including Japan, China, and Nigeria. Edible mushrooms are known to be safe and devoid of adverse side effects. Therapeutically fungi are of specific interest because they are eukaryotic organisms and their metabolism is closely related to man and animals. Mushrooms are macro-fungi and are now widely accepted as an untapped source of potentially powerful natural products of pharmacological significance (2). Various bioactive compounds extracted from mushrooms fruiting bodies, cultured mycelia and cultured broth are polysaccharides, glycosides, proteins, flavonoids and carotenoids (3). Most of these compounds function as Biological response modifiers (BRM) which have been shown to enhance various immune responses (4).

In recent years chemists and immunologists have discovered the importance of the polysaccharides inherent in mushrooms. Studies of fungi have shown that the Basidiomycetes and Ascomycetes divisions are an immense source of biologically active components, but few species were tested for therapeutic importance (5). Pleuroteus ostreatus is a gilled mushroom commonly known as milky or Oyster mushroom and one of the mostly consumed mushrooms. It is of Division: Basidiomycota, Class: Agaricomycota and order: Agaricales. Records of health-promoting properties such as antioxidant, antimicrobial, anticancer, cholesterol-lowering and immunostimulatory effects have been reported for some species of mushrooms (6). The in vivo antibacterial activity and effect of methanol extract of $P$. ostreatus on haematological parameters and serum enzymes after 7 days oral administration, against $S$. aureus inoculated Wistar albino rats were investigated in this study.

\section{MATERIALS AND METHODS \\ Collection and Identification of Mushroom Species:}

Fresh fruiting bodies of Pleurotus ostreatus were obtained from a commercial farm at latitude $07^{\circ} 40$ North and longitude $04^{\circ} 30$ East, Osun State in Nigeria. The fully matured mushrooms were packed in a polyethene bag, labelled and transported to the microbiology laboratory within $24 \mathrm{~h}$ of collection. The mushroom was identified by a Botanist. Macroscopic identification was based on colour, odour, and spore print and morphological characteristics. The mushroom was further identified based on gene sequences using molecular characterization. The Oyster mushroom used for the study was $99.09 \%$ organism matched of Pleurotus ostreatus strain PAsp14 (7).

\section{Preparation of Extracts}

The mushrooms were dried at ambient temperature for 2 weeks and processed using a cold extraction method as described by Oyekanmi et al. (7). The mushroom powder was soaked at the ratio of 1:10 of ground powder to 98 $\%$ Methanol. The mouth of the beaker was covered with foil paper to prevent evaporation and the mixture was allowed to stand at room temperature $\left(28^{\circ} \mathrm{C}\right.$ to $\left.30^{\circ} \mathrm{C}\right)$ for $48 \mathrm{~h}$ with frequent agitation. The supernatant was filtered using a muslin cloth and filtrate was concentrated in vacuo in the rotary evaporator at $40{ }^{\circ} \mathrm{C}$. The extract was evaporated to dryness in small vials at $40{ }^{\circ} \mathrm{C}$ in the laboratory oven (Lab-Tech). A stock solution of $500 \mathrm{mg} / \mathrm{ml}$ concentration was prepared using sterile physiological saline $(0.85$ $\%$ ) as diluent and sterilized using $0.45 \mathrm{~mm}$ diameter membrane filter before use. Concentrations required were prepared from the stock using $\mathrm{RV} / \mathrm{O}$ where $\mathrm{R}=$ required concentration, $\mathrm{V}=$ required volume, and $\mathrm{O}=$ original concentration. They were labelled and preserved at $4^{\circ} \mathrm{C}$.

\section{Collection of Bacterial Isolate}

Clinical isolate of Staphylococcus aureus was obtained from Federal Medical Centre, Owo, Nigeria.

\section{Preparation of inoculums}

The bacterial species was isolated from the 
wound sample and obtained on agar slant, labelled, and preserved at $4{ }^{\circ} \mathrm{C}$. The isolate was sub-cultured on Manitol salt agar and incubated at $37{ }^{\circ} \mathrm{C}$ for $24 \mathrm{~h}$. The bacterial growth was confirmed using gram staining procedures and biochemical tests. A broth culture of actively growing bacteria was prepared in peptone water. The turbidity of $24 \mathrm{~h}$ actively growing bacteria suspension was adjusted to obtain turbidity optically comparable to that of $0.5 \mathrm{Mc}$ Farland standards $\left(10^{6} \mathrm{Cfu} / \mathrm{ml}\right)$. Each of the experimental animals was inoculated with $0.3 \mathrm{ml}$ of the bacterial (S. aureus) suspension.

\section{Management of Experimental Animals}

Thirty (30) apparently healthy Wistar albino rats of body weight $82.0 \mathrm{~g}$ to $92.2 \mathrm{~g}$ were obtained from the animal house of the College of Health Sciences, Osun State University Osogbo. The animals were housed in plastic cages and fed with standard rat feed once a day and clean drinking water. The beddings were laid with wood powder and changed daily. The room temperature was maintained and the light was 12 $\mathrm{h}$ light and $12 \mathrm{~h}$ darkness. Animal maintenance, use, and care was according to the National Institute of Health (NIH) animal care guidelines (8).

\section{Experimental Design}

The experiment was conducted in a Completely Randomized Design (CRD). The Wistar rats were distributed into 6 groups of 5 and allowed to acclimatize in 7 days. The cages were properly labelled and each rat was also marked employing different dyes, on the tail for proper identification. Experimental animals were inoculated orally with $0.3 \mathrm{ml} \mathrm{S}$. aureus bacterial suspension of standard inoculums $\left(1 \times 10^{6} \mathrm{Cfu} / \mathrm{ml}\right)$ and allowed for 3 days incubation period. The graded dose of extract administered was determined using $\mathrm{LD}_{50}>5000 \mathrm{mg} / \mathrm{kg}$ (5). A graded dose $625 \mathrm{mg}$ (low), $1250 \mathrm{mg}$ (moderate) and $2500 \mathrm{mg} / \mathrm{kg}$ body weight (high) was administered for 7 consecutive days. The animals were nurtured for another 7 days with feed and drinking water only. After 7 days post-treatment the animals were starved for $12 \mathrm{~h}$, sacrificed using cervical dislocation method, and the blood sample was collected from the heart. Controls were set up which include: Control 1- Normal control (placebo): not inoculated but administered with $0.85 \% \mathrm{NaCl}$ (Sodium chloride solution); Control 2- Positive control: Inoculated and administered with $13.33 \mathrm{mg} / \mathrm{kg}$ body weight ciprofloxacin capsule; Control 3-Negative control: Inoculated with $S$. aureus but not administered with antibacterial. Groups 4, 5, and 6 were the test groups, inoculated and administered with $625 \mathrm{mg}, 1250 \mathrm{mg}$, and 2500 mg doses of the extract respectively.

\section{Pilot Study:}

On the 9th day of the experiment a preliminary clinical study was conducted on the groups (groups 3, 4 and 5) that manifested skin ulcer. Randomly selected rats were subjected to wound culture, blood culture, colony count, WBCT, WBCD and HCT level.

\section{Microbiological Culture}

After six days of antibacterial administration, groups 3 and 4 demonstrated skin ulcer. A rat with skin ulcer was randomly selected from each of the groups for wound and blood culture, and colony count. The skin surrounding the wound was sterilized with $70 \%$ alcohol and the ulcerated surface was swab with the sterile swab stick under aseptic condition. The sample was cultured on the Manitol salt agar and incubated at $37{ }^{\circ} \mathrm{C}$ for $24 \mathrm{~h}$. A blood sample was collected from the heart of the rat and subjected to blood culture and colony count. After 7 days post- administration of $P$. ostreatus, group 1 to 6 were subjected to blood culture and colony count as described by Cheesbrough, (9) with a little modification. Blood sample was collected under aseptic condition and inoculated into cooled sterile peptone water at ratio 1:10 dilution, incubated at $37{ }^{\circ} \mathrm{C}$ for 3 days. On the third day, serial dilution $\left(10^{-1}\right.$ to $\left.10^{-5}\right)$ of one volume of cultured broth was prepared. The diluted cultured broth was then sub-cultured on freshly prepared sterile Manitol salt agar and incubated at $37^{\circ} \mathrm{C}$ for $24 \mathrm{~h}$. The growth was further confirmed using gram staining procedures and biochemical tests. Bacterial (S. aureus) colonies on the plate were counted and recorded.

\section{Biochemical and Haematological Evaluation of Albino rats}

A blood sample obtained from the rat were delivered into plain bottle and dipotasium Ethylene diamine tetraacetic acid $\left(\mathrm{K}_{2}\right.$ EDTA) bottle. The serum was analyzed for Aspartate aminotransferase (AST), Alanine aminotransferase (ALT), Alkaline phosphatase (ALP), Total protein, Urea and Creatinine, using enzyme maker kits from Randox. The EDTA blood sample was analysed for haematological parameters (Haematocrit (HCT) level, Leucocyte count, Leucocyte differential count (Neutrophil, 
Lymphocyte, Eosinophil, Monocyte, Basophil), and Red blood cell count (RBC)) using standard operating procedures $(9)$.

\section{Data analysis}

Data were expressed as means \pm standard error of mean and subjected to one-way analysis of variance (ANOVA). Treatment means were compared using Turkey's Multiple Comparison tests with the aid of Graph Pad Prism 5 at $\mathrm{P}<0.05$.

\section{RESULTS}

\section{Effect of the Extract on the Temperature and weight of Albino Rats}

Figure 1.1 showed numerical variation in the temperature of albino rats: Normal control showed an initial temperature of $37^{\circ} \mathrm{C}$ which was maintained till the end of the experiment. All the inoculated rats had temperature variation within $36{ }^{\circ} \mathrm{C}$ to $38^{\circ} \mathrm{C}$ during the incubation period and within 4 days administration of antimicrobials. Finally, after 7 days post-administration of antibacterial, control and tests maintained normal temperature except for $625 \mathrm{mg}$ dose that was numerically raised.

In Figure 1.2, the average body weight during three days incubation period was reduced in all the inoculated rats; after 7 days administration of the antibacterial there was a mild increase in weight. This was followed by a drastic weight increase in group 4 after 7 days post-treatment. Normal control demonstrated gradual weight increase till the end of the experiment (90 to $96 \mathrm{~g}$ ) while group 3 (negative control) showed a better weight increase from 87 to $101 \mathrm{~g}$, but a very mild increase in the positive control (90 to $92 \mathrm{~g}$ ) (Figure 1.2). The treatments demonstrated no statistical variation in the average body weight $\mathrm{P}<0.05$.

\section{Clinical Changes in the Albino Rats after 6 days Administration of Antibacterial, and 7 Days Post-treatment}

In the preliminary test in Table 1.1, $80 \%$ (4 of 5) of group 3 (negative control) and 4 (625 $\mathrm{mg}$ ) demonstrated skin ulcer (Plate 1.1) which yielded heavy bacterial growth of $S$. aureus. The negative control and $625 \mathrm{mg}$ produced moderate growth of $S$. aureus in blood culture while 1250 mg yielded mild bacterial growth. After 7 days administration of antimicrobials number of colony counted in cultured blood was highest in the negative control and least in $1250 \mathrm{mg}$ (Table 1.1). White blood cell total and neutrophil counts were numerically lowest in $1250 \mathrm{mg}$ and highest in negative control $\left(16.6 \times 10^{9} / \mathrm{L} ; 73 \%\right)$.
Consequently, lymphocyte was numerically highest in $1250 \mathrm{mg}(30 \%)$ and least in the negative control (27\%). Eosinophil, monocyte, and basophil were within $0 \%$ to $1 \%$ for the three groups. Table 1.1 showed the haematocrit level ranging from $47 \%$ (Group 5) to $45 \%$ (Group 3). After 7 days post-administration of the extract, colony count was significantly low in group 1 (normal control), 2 (positive control), 5 (1250 $\mathrm{mg})$, and $6(2500 \mathrm{mg})$ but high in group 3 (negative control) and $4(625 \mathrm{mg}) \mathrm{P}<0.05$ (Table 1.1)

\section{Effect of $P$. ostreatus on Haematological and Biochemical Parameters of the Inoculated Rats}

The haematological parameters of the albino rats after 7 days post-administration of $P$. ostreatus demonstrated highest White blood cell total count (WBCT) in the negative control $\left(14.54 \pm 2.39^{\mathrm{b}} \times 10^{9} / \mathrm{L}\right)$ and least in $2500 \mathrm{mg}$ dose $\left(6.98 \pm 1.20^{\mathrm{a}} \times 10^{9} / \mathrm{L}\right)$ (Figure 1.3). Neutrophil was significantly raised in the negative control and $625 \mathrm{mg}$; lymphocyte was statistically raised in groups 1 (normal control) and $6(2500 \mathrm{mg}$ ) while eosinophil, basophil and monocyte were 0.00 to $0.40 \%$ in all the groups and were within normal range $\mathrm{P}<0.05$ (Figure 1.3). The haematocrit level and Red cell count demonstrated no significant variation in both treatment and control $\mathrm{P}<0.05$.

Figure 1.4 showed serum biochemical parameters of albino rats after seven days postadministration of $P$. ostreatus extract. The tests demonstrated Alanine amino transaminase (ALT) value ranging from $30.67 \pm 1.76$ to $49.33 \pm$ $11.10 \mathrm{IU} / \mathrm{L}$ and within normal control $(54.50 \pm$ $7.22 \mathrm{IU} / \mathrm{L}$ ) (Figure 1.4). Serum Aspartate amino transaminase (AST) was the least in the positive control $(71.33 \pm 20.22 \mathrm{IU} / \mathrm{L})$ and highest in the normal control $(113.00 \pm 8.73 \mathrm{IU} / \mathrm{L})$; and Alkaline phosphatase (ALP) level ranged from $34.33 \pm 9.77 \mathrm{IU} / \mathrm{L}$ (negative control) to $59.67 \pm$ $1.67 \mathrm{IU} / \mathrm{L}(1250 \mathrm{mg})$ (Figure 1.5). Total protein was numerically highest in $1250 \mathrm{mg}$ and least in $625 \mathrm{mg}$. Figure 1.4 showed urea level ranging from $5.37 \pm 0.79 \mathrm{Mmol} / \mathrm{L}$ ( $625 \mathrm{mg}$ dose) to $8.67 \pm$ $0.61 \mathrm{Mmol} / \mathrm{L}$ (normal control), and creatinine level was significantly raised in group 2 (positive control) $139.00 \pm 2.65^{\mathrm{c}} \mu \mathrm{mol} / \mathrm{LP}<0.005$.

\section{DISCUSSION}

In the search for new antimicrobials from natural sources, mushrooms are of particular interest due to their potential as a source of secondary metabolites (10). 
Therapeutic evaluation of $P$. ostreatus extract on $S$. aureus infected albino rats revealed a slightly raised rectal temperature following inoculation; which is indicative of active infection. According to Ochei and Kolhatkar (11), the rectal temperature of rats is between 36 and $40{ }^{\circ} \mathrm{C}$. Although in all the groups, the temperature was within the normal values throughout the experiment but a gradual decline after 2 days administration of antibacterial until it dropped to the starting temperature was indicative of a positive response to treatment; consequently an improvement in the experimental animals. The only exceptional case was the slight increase in temperature after 7 days post-administration of $P$. ostreatus in $625 \mathrm{mg}$ dose. This could mean incomplete elimination of the infection and might allowed proliferation after a full course treatment. It could be inferred that $625 \mathrm{mg} / \mathrm{kg}$ body weight was not adequate to eradicate $S$. aureus infection.

The initial reduction in the average body weight observed within the first 3 days of the experiment could be attributed to the effect of the bacterial on the body system and the process of the immune system in response to the foreign substance. The mild weight increase in $P$. ostreatus treatment as compared with better weight gain in the negative control could indicate that bioactive compounds in $P$. ostreatus did not encourage weight gain and might be of value in limiting obesity and maintaining normal body weight in health (12). The mild weight gain obtained in the experimental animals treated with extract is similar to the work of some researchers $(13,14,15)$ who reported the benefits of Pleurotus spp. in reducing inflammation and weight gain. It also corroborates the study of Fard et al. (16) who reported lower body weight in chickens fed with $2 \%$ mushroom supplement.

Skin ulcers observed in the negative control and $625 \mathrm{mg}$ dose could result from $S$. aureus infection. P. ostreatus administered led to significantly reduced colony count; indicating its potency against the pathogens; and appreciable improvement was obtained with an increased dose. The healing effect observed in the experimental animals was dose-dependent.

Pleurotus ostreatus dosage ranging from 1250 to $2500 \mathrm{mg} / \mathrm{kg}$ body weight was effective against pathogenic staphylococcus. The average colony count in seven days post-treatment cultured blood also indicated that $P$. ostreatus administration at 1250 to $2500 \mathrm{mg}$ doses produced insignificant low colony count that was comparable with $13.33 \mathrm{mg}$ Ciprofloxacin and placebo while $625 \mathrm{mg}$ could not produce recovery. It could be inferred that $P$. ostreatus at 1250 to $2500 \mathrm{mg}$ dose compete favorably well with $13.33 \mathrm{mg}$ Ciprofloxacin; and able to maintain the clinical recovery without relapses. However an under-dose treatment may not be effective against killing or eradication of the pathogenic bacteria (17). P. ostreatus may contain bioactive compounds that are potent in vivo against $S$. aureus infection.

Blood leucocytes are body soldiers that are involved in eliciting an immune response against infectious agents and are raised in bacterial infection. In the study, leukocytes and neutrophils were reduced gradually with increased dose. Significant leukocytosis due to neutrophilia was observed in the negative control and $625 \mathrm{mg}$ treatment. The colony count and haematological results were in harmony and discouraged the administration of $625 \mathrm{mg} / \mathrm{kg} P$. ostreatus against Staphylococcus aureus infection. Lymphocytes are moderately lower in the system when compared with neutrophils in health; they are increased at a young age and reduced in viral trauma, impaired lymphopoiesis (immunosuppression), and immunodeficiency; in this study, the lymphocytes were within normal control range. Eosinophils are raised in some parasitic infection while increased monocytes and basophils values are not clinically significant but in this study, they were maintained within the normal range. The test rats demonstrated haematocrit levels that was comparable to normal control and indicative of normal erythropoiesis. This could be attributed to the nutritional values derived from the extract.

A seven days' administration of $P$. ostreatus was beneficial to the serum enzymes and kidney markers. Alanine amino transaminase (ALT), Aspartate amino transaminase (AST) and Alkaline phosphatase (ALP) are biomarkers of liver function test; they are raised in metabolic disorders with secondary liver disease. The ALT, AST, and ALP were normal in all the treatments indicating that $P$. ostreatus had no deleterious observable effect on the liver enzymes which may indicate no hepatocellular damage. A decrease in serum protein is an indication of impaired synthetic functions of the liver. The protein level was within the normal range indicating that $P$. ostreatus posed no danger to the hepatocytes and liver enzymes. Serum urea and creatinine are reliable markers of renal functions and the extent of renal damage is usually assessed by increased serum level of these enzymes, however, this study demonstrated a decrease 
compared to normal serum urea and creatinine level throughout the graded doses. This suggests that $P$. ostreatus at doses up to $2500 \mathrm{mg} / \mathrm{kg}$ might not be harmful to renal cells.

\section{CONCLUSION}

P. ostreatus at doses ranging from 1250 to $2500 \mathrm{mg}$ are potent against $S$. aureus infection whereas a low dose of 625 may not produce a cure against pathogenic $S$. aureus. The biochemical properties are suggestive of safety and tolerance of the bioactive agents present in the mushroom to the body system. This information could be useful in the production of new antimicrobials of commercial value which will be less toxic to the body system. However further studies are required to isolate the bioactive compounds inherent in the mushroom species.

Conflict of Interest: There is no conflict of interest.

Acknowledgments: The authors appreciate Mr. I.I. Ogunlowo of the Department of Pharmacognosy, Obafemi Awolowo University, Ile-Ife, Mr. K.O. Olabiyi, and Dr, T.G. Atere College of Health Sciences, Osun State University Osogbo for their technical assistance.

\section{REFERENCES}

1. Jawetz E, Melnick JL, Adelberg EA, Hobden JA, Miller S, Morse SA et al., A Lange medical book New York; Toronto : McGraw-Hill Education cop., 2019.

2. Patel S, Goyal A. "Recent developments in mushrooms as anticancer therapeutics: a review," 32012 Biotechnology 2 (1): 1-15.

3. Kirk PM, Stalpers JA, Minter DW, Cannon PF. Dictionary of the Fungi. CABI Publishing, CAB International, Wallingford, UK. 2011

4. Nisar J, Mustafa I, Anwar H, Sohail MU, Hussain G, Ullah MI, et al., Shiitake culinary-medicinal mushroom, Lentinus edodes (Agaricomycetes): A species with antioxidant, immunomodulatory, and hepatoprotective activities in hypercholesterolemic rats. Int. J. of Med. Mushrooms, 2017, 19(11): 981-990.

5. Smitha, H, Doyle S, Murphy R. Filamentous fungi as a source of natural antioxidants, Food Chem., 2015, 185 (2015)389-397.
6. Chang ST, Wasser SP. "The role of culinarymedicinal mushrooms on human welfare with a pyramid model for human health," Int. J. Med. Mushrooms, 2012, 14(2): 95-134.

7. Oyekanmi BA, Onifade AK, Osho IB, Adetuyi FC. Haematological and biochemical properties of Pleuroteus ostreatus mushroom species. Niger. J. Mycology, 2019, 11:102-114

8. National Res Council (US) Committee for the update for the care and use of Laboratory Animals National Academies Press (US) 2011 Google Scholar

9. Cheesebrough M. District Laboratory Practice in Tropical Countries Part 2 Cambridge University press 2000

10. Bhardwaj A, Sharma D, Jodan N, Agrawal PK. Antimicrobial and phytochemical screening of endophytic fungi isolated from spikes of Pinus roxburghii. Arch. Clin. Microbiol. 2015, 6 (3): 19.

11. Ochei J, Kolhatkar A. Medical Laboratory Science Theory and Practice Tata Mcgraw-Hill Publishing Company Limited: New Delhi. $6^{\text {th }}$ Reprint, 2007.

12. Mao GH, Ren Y, Feng WW, Li Q, Wu HY, Jin D et al., Antitumor and immunomodulatory activity of a water-soluble polysaccharide from Grifola frondosa. Carbohydr. Polym. 2015, 134: 406-412.

13. Chang CJ, Lin CS, Lu CC, Martel J, Ko YF, Ojcius DM et al., Ganoderma lucidum reduces obesity in mice by modulating the composition of the gut microbiota. Nat. Commun. 2015, 6:7489. http://dx.doi.org/10.1038/ncomms8489.

14. Delzenne NM, Bindels LB. Gut microbiota: Ganoderma lucidum, a new prebiotic agent to treat obesity? Nat. Rev. Gastroenterol. He patol.2015, 12 : $553-554$. http://dx.doi.org/10.1038/nrgastro.2015.137.

15. Murphy EA, Velazquez KT, Herbert KM. Influence of high-fat diet on gut microbiota: A driving force for chronic disease risk. Curr. Opin. Clin.l Nut. Metab. Care 2015, 18:515-520.

16. Fard SH, Toghyani M, Tabeidian SA. Effect of oyster mushroom wastes on performance, immune responses and intestinal morphology of broiler chickens. Int. J. Recycl. Org. Waste Agric. 2014, 3: 141.

17. Kalam S, Gul MZ, Singh R, Ankati S. Free radicals: Implications in etiology of chronic diseases and their amelioration through nutraceuticals. Pharmacologia, 2015, 6: 11-20.

\section{How to cite this article:}

Oyekanmi, B. A., Onifade, A. K., Osho, I. B., Ajayi O. T. in vivo antibacterial and therapeutic properties of $P$. ostreatus against Staphylococcus aureus. Research Journal of Health Sciences, 2021, 9(3): 273-281 
Table 1.1: Clinical Changes in the Albino Rats after 6 days Administration of antibacterial and 7 days Post-

\begin{tabular}{|c|c|c|c|c|c|c|c|c|c|c|c|c|}
\hline G & $\begin{array}{l}\text { Skin } \\
\text { ulcer } \\
(\%)\end{array}$ & $\begin{array}{l}\text { W/S } \\
\text { culture }\end{array}$ & $\begin{array}{l}\text { Blood } \\
\text { culture }\end{array}$ & $\begin{array}{l}\text { Cc 6 } \\
\left(\times 10^{3}\right. \\
\text { Cfu/ml })\end{array}$ & $\begin{array}{l}\text { Ce 7Post } \\
\left(\times 10^{4}\right. \\
\text { Cfu/ml })\end{array}$ & $\begin{array}{l}\text { WBCT } \\
\left(10^{9} / \mathrm{l}\right)\end{array}$ & $\begin{array}{l}N \\
(\%)\end{array}$ & $\begin{array}{l}L \\
(\%)\end{array}$ & $\begin{array}{l}E \\
(\%)\end{array}$ & $\begin{array}{l}M \\
(\%)\end{array}$ & $\begin{array}{l}B \\
(\%)\end{array}$ & $\begin{array}{l}\text { HC } \\
\text { T } \\
(\%)\end{array}$ \\
\hline G1 & 0 & NA & NG & NA & $2.00 \pm 0.63^{a}$ & NA & NA & NA & NA & NA & NA & NA \\
\hline G2 & 0 & NA & NG & NA & $2.00 \pm 1.00^{\mathrm{a}}$ & NA & NA & NA & NA & NA & NA & NA \\
\hline G3 & 80 & +++ & ++ & 110 & $\begin{array}{l}32.00 \pm 6.10 \\
\mathrm{~b}\end{array}$ & 16.6 & 73 & 27 & 00 & 01 & 00 & 45 \\
\hline G4 & 80 & +++ & ++ & 95 & $\begin{array}{l}43.40 \pm 6.20 \\
\mathrm{~b}\end{array}$ & 15.2 & 71 & 28 & 00 & 01 & 00 & 47 \\
\hline G5 & 0 & NA & + & 36 & $5.60 \pm 3.20^{\mathrm{a}}$ & 13.4 & 69 & 30 & 00 & 01 & 00 & 47 \\
\hline G6 & 0 & NA & NA & $\mathrm{NA}$ & $1.80 \pm 1.10^{\mathrm{a}}$ & NA & NA & NA & NA & NA & NA & NA \\
\hline
\end{tabular}

treatment

key: $\mathrm{g} 1=$ normal control; $\mathrm{g} 2=$ positive control; $\mathrm{g} 3$ = negative control; $\mathrm{g} 4=625 \mathrm{mg}$ dose; $\mathrm{g} 5=1250 \mathrm{mg}$ dose; $\mathrm{g} 6=2500 \mathrm{mg}$ dose; wbct = total white blood cell count; $\mathrm{n}=$ neutrophil; $1=$ lymphocyte; $\mathrm{e}=$ eosinophil; $\mathrm{m}=$ monocyte; $\mathrm{b}=$ basophil; $\mathrm{g}=$ group; $\mathrm{na}=$ not applicable; $\mathrm{ng}=$ no growth; $\mathrm{cc} 6=$ colony count after 6 days administration of antibacterial; cc 7post $=$ colony count after 7 days post- administration of antibacterial, different superscripts along the same vertical axis at $\mathrm{P}<0.05$ is significant

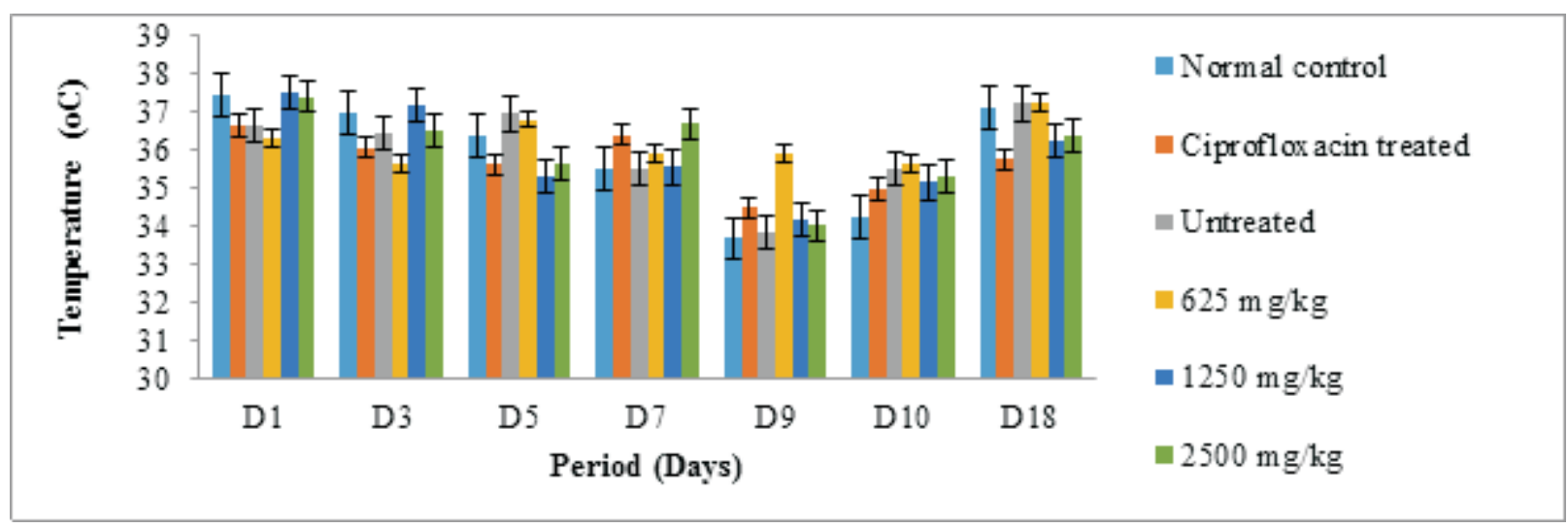

Figure 1: Effect of $P$. ostreatus on the temperature of albino rats inoculated with $S$. aureus key: $\mathrm{d} 1=$ day 1 of the experiment; $\mathrm{d} 3=$ day $3 ; \mathrm{d} 5=$ day $5 ; \mathrm{d} 7=$ day $7 ; \mathrm{d} 9=$ day $9 ; \mathrm{d} 10=$ day $10 ; \mathrm{d} 18=$ day $18 ;$ untreated $=$ negative control; $* \mathrm{p}<0.05$ is a significant difference

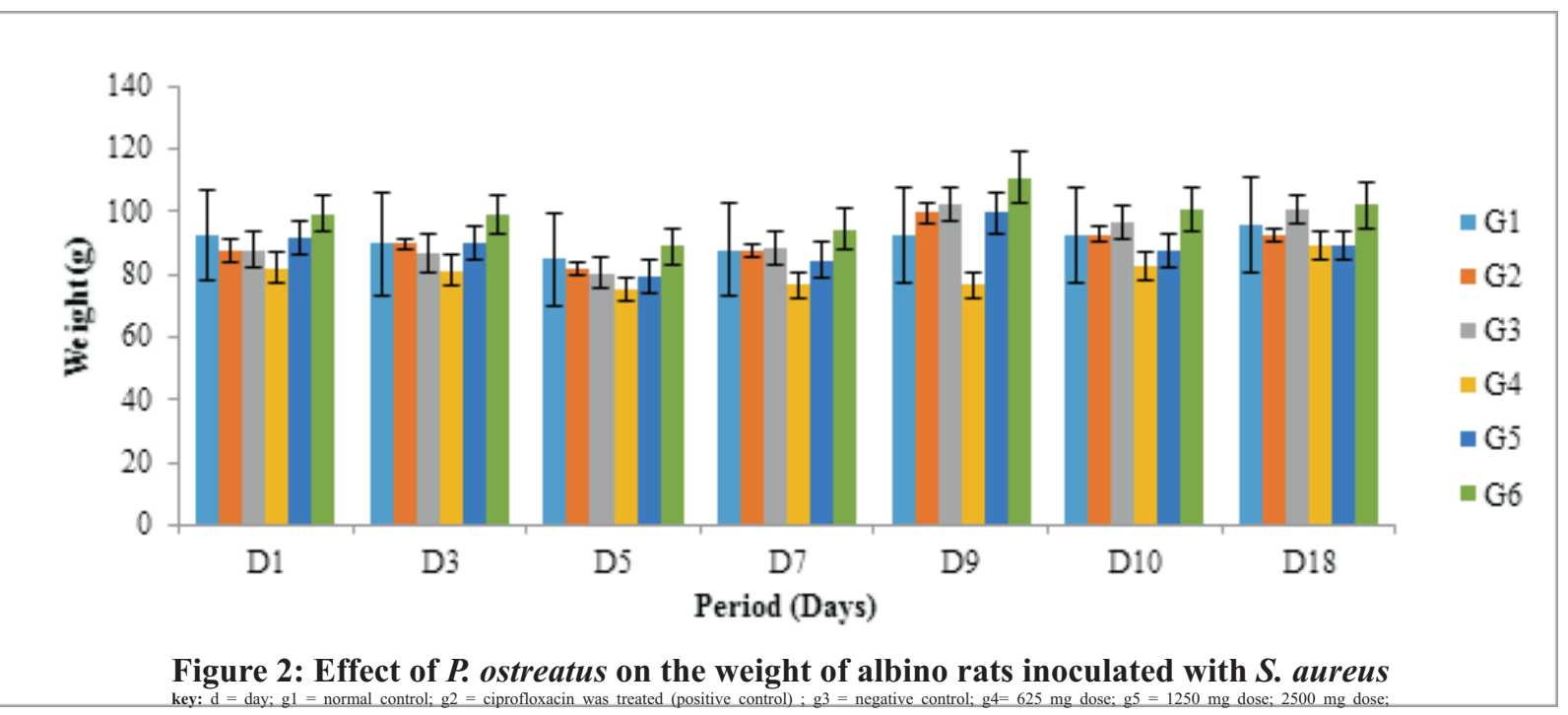

${ }^{*} p<0.05$ is a significant difference 


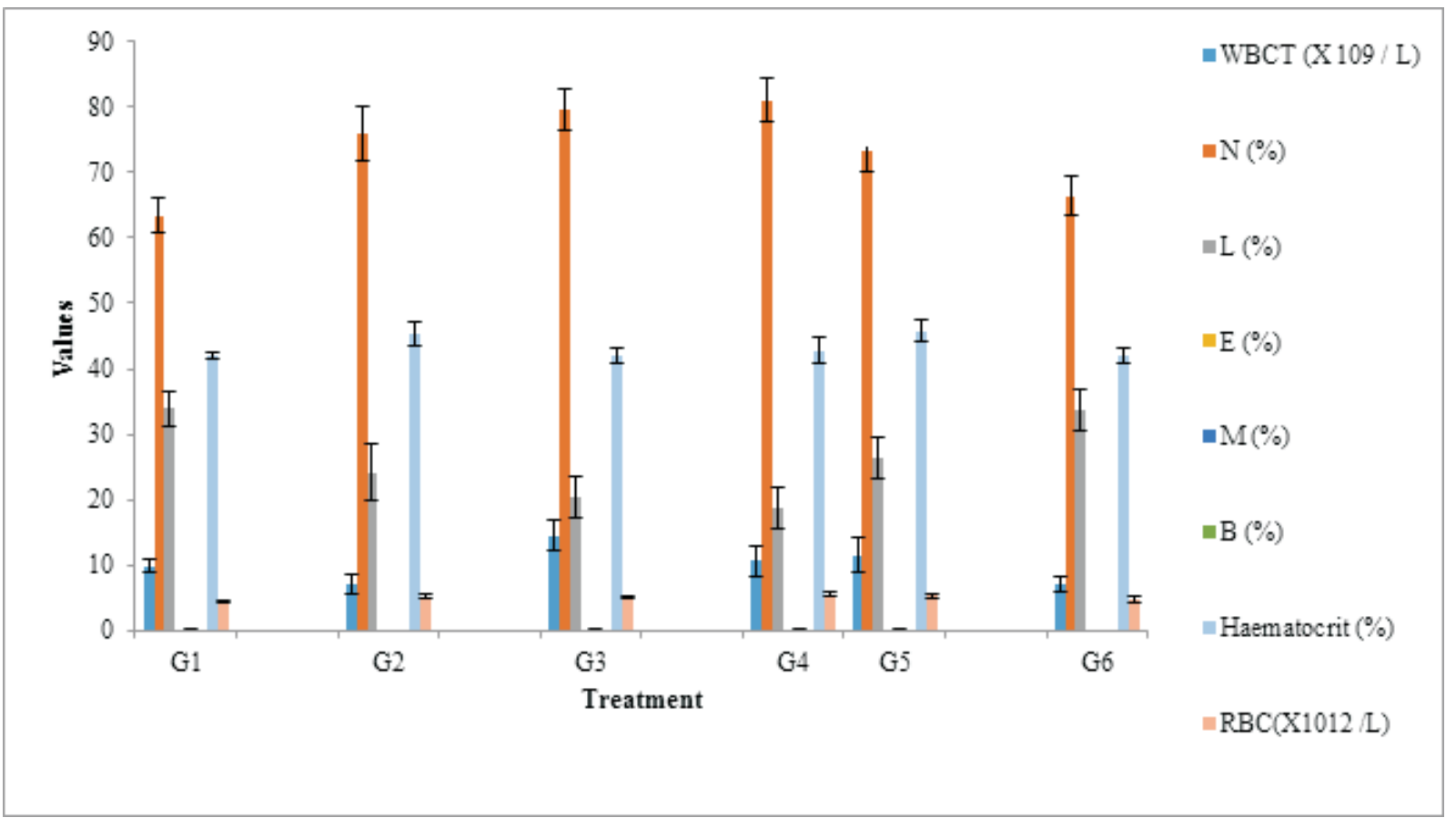

Figure 3: Effect of P. ostreatus on haematological parameters of albino rats inoculated with $S$. aureus key: $\quad$ wbct $=$ total white blood cell count; $r b c=$ red cell count; $\mathrm{n}=$ neutrophil; $1=$ lymphocyte; $\mathrm{e}=$ eosinophil; $\mathrm{m}=$ monocyte; $\mathrm{b}=$ basophil; $\mathrm{n}=5 ; \mathrm{g} 1=$ normal control; $\mathrm{g} 2=$ ciprofloxacin treated; $\mathrm{g} 3=$ negative control; $\mathrm{g} 4=625 \mathrm{mg} ; \mathrm{g} 5=1250 \mathrm{mg}$ and $\mathrm{g} 6=2500 \mathrm{mg} *(\mathrm{p}<0.05)$ is a significant difference.

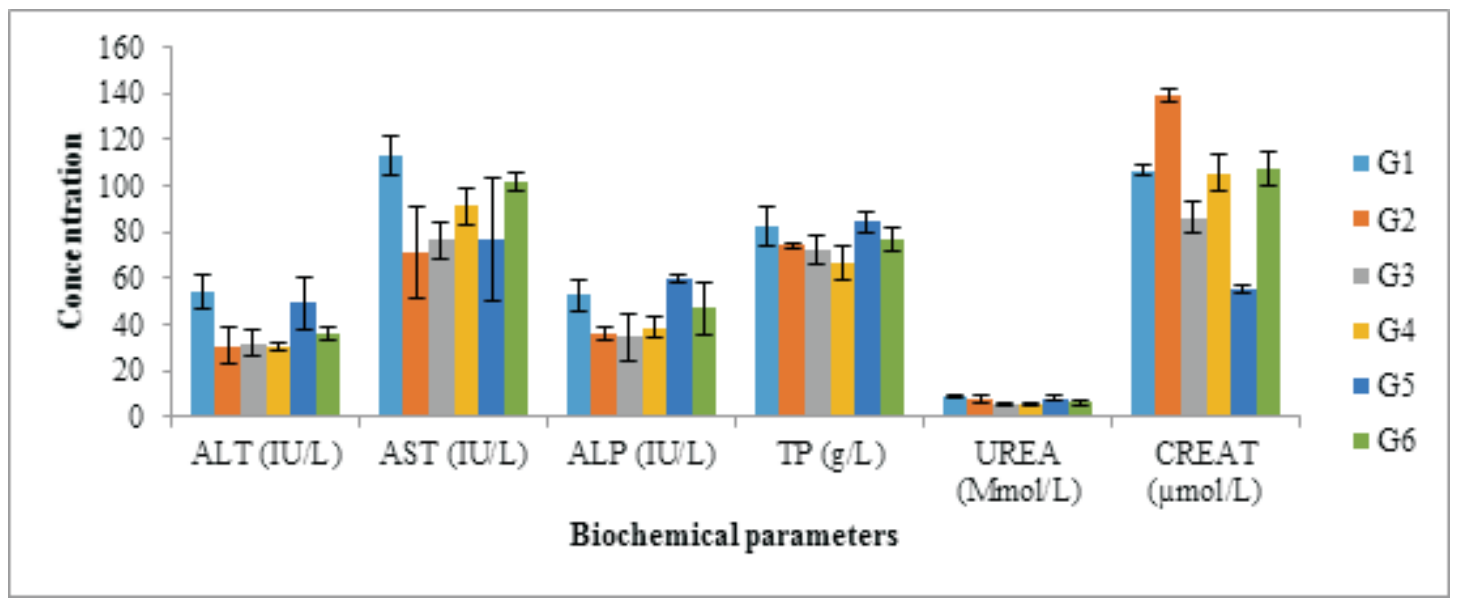

Figure 4: Effect of $P$. ostreatus on biochemical parameters of albino rats inoculated with $S$. aureus key : alt $=$ alanine amino transaminase; ast $=$ aspartate amino transaminase; alp $=$ alkaline phosphatase; $\mathrm{tp}=$ total protein; creat $=$ creatinine; $\mathrm{g} 1=$ normal $\mathrm{control}$; $\mathrm{g} 2=$ ciprofloxacin treated; $\mathrm{g} 3=$ negative control; $\mathrm{g} 4=625 \mathrm{mg}$ dose; $\mathrm{g} 5=1250 \mathrm{mg}$ dose and $\mathrm{g} 6=2500 \mathrm{mg}$ dose $*(\mathrm{p}<0.05)$ is a significant difference

A

A

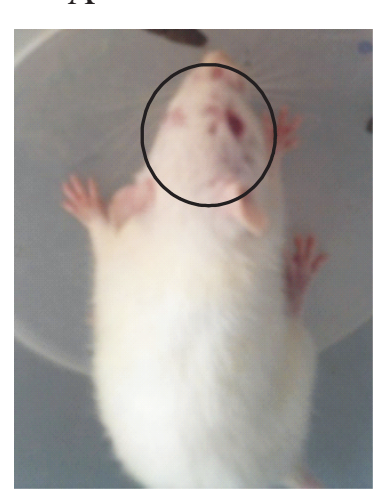

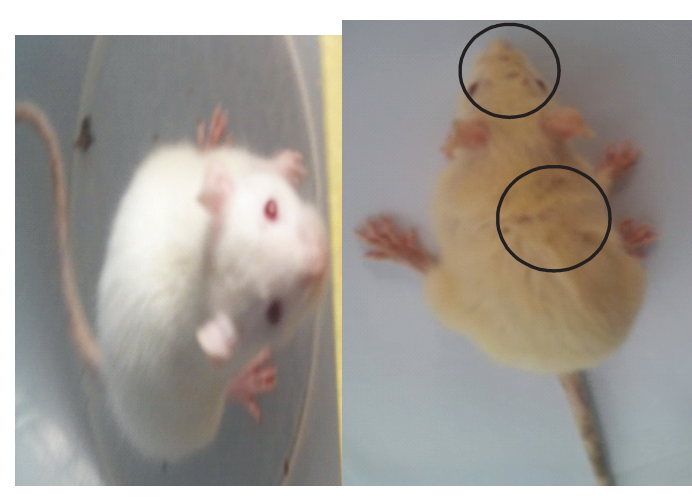

B

Plate 1.1: Wistar albino rats in S. aureus infection showed ulcerated skin (ring) in $625 \mathrm{mg}$ (A) and the negative control $(C)$ as compared with healthy skin in normal control $(B) \times 0.05$ 